\title{
Multienzyme and Antibacterial Potential of Bacteria Isolated from gut of Asian Honey Bee (Apis cerana Indica), Lahore Using Culture Dependent Method
}

Iram Liaqat ${ }^{{ }^{*}}$

https://orcid.org/0000-0002-4638-8253.

Muhammad Mubin ${ }^{2}$

https://orcid.org/0000-0001-8319-1962

Maleeha Anwar Chaudhry ${ }^{1}$

https://orcid.org/0000-0003-3052-1520

Najma Arshad ${ }^{3}$

https://orcid.org/0000-0002-0244-6757

Muhammad Afzaal ${ }^{4}$

https:// orcid.org/0000-0002-2369-2658

Chaman Ara $^{5}$

https://orcid.org/0000-0003-4567-0078
Nazish Mazhar Ali ${ }^{1}$

https://orcid.org/0000-0001-8740-4515

Andleeb Anwar Sardar 6

https://orcid.org/0000-0003-0708-8925

Umer Farooq Awan ${ }^{6}$

https://orcid.org/0000-0003-3955-2905

Sumera Sajjad ${ }^{7}$

https://orcid.org/0000-0001-6982-5965

Farzana Rashid ${ }^{7}$

https://orcid.org/0000-0002-5519-3175

Shaukat Ali ${ }^{1}$

https://orcid.org/0000-0003-2481-1978

${ }^{1}$ GC University, Microbiology Laboratory, Department of Zoology, Lahore, Pakistan; ${ }^{2}$ University of Agriculture, Centre of Agricultural Biochemistry and Biotechnology, Faisalabad, Pakistan; ${ }^{3}$ University of Lahore, Department of Zoology, Lahore, Pakistan; ${ }^{4} \mathrm{GC}$ University, Sustainable Development Study Centre, Lahore, Pakistan; ${ }^{5}$ University of the Punjab, Department of Zoology, Lahore, Pakistan; ${ }^{6} \mathrm{GC}$ University, Department of Botany, Lahore, Pakistan; ${ }^{7}$ Lahore College for Women University, Department of Zoology, Lahore, Pakistan.

Editor-in-Chief: Alexandre Rasi Aoki

Associate Editor: Renata Marino Romano

Received: 2021.01.12; Accepted: 2021.05.25.

${ }^{*}$ Correspondence: iramliaq@hotmail.com; Tel.: +92-300-6477459 (I.L.).

\section{HIGHLIGHTS}

- The current study focuses on antibacterial potential of bacterial isolates from gut of Asian $\mathrm{HB}$, Apis cerana Indica F. (Hymenoptera: Apidae), against human pathogens.

- PCR study confirmed the presence of bacteriocins by successful amplification of important antimicrobial peptide biosynthesis genes spaS and spoA.

- Results suggested HB gut is a home to bacteria that possess antimicrobial activity and important enzymes with antimicrobial potential

- This is the first report demonstrating the antimicrobial potential of bacteria isolated from gut of HB (A. cerana) against human pathogens. 
Abstract: The bacteria residing in the gut of honey bees $(\mathrm{HB})$ has demonstrated a significant role in protecting bees against various pathogens, production of honey and wax. However, no information exists about the antibacterial potential of bacterial isolates from gut of Asian HB, Apis cerana Indica F. (Hymenoptera: Apidae), against human pathogens. This study aims to investigate the antibacterial and multienzyme potential of aerobic bacteria from $A$. cerana gut using culture dependent approach. A total of 12 $\mathrm{HB}$ gut bacteria were characterized morphologically and biochemically. These strains were further screened for their antimicrobial activity against pathogenic human microorganisms Escherichia coli, Pseudomonas aeruginosa, Klebsiella pneumonia, Bacillus licheniformis and Bacillus subtilis using cross streak (primary screening) and agar well diffusion methods (secondary screening). Preliminary characterization of cell-free supernatant (CFS) of two promising isolates was performed by measuring lactic acid concentrations, enzymatic digestion of antimicrobial compounds, stability over a range of temperature, $\mathrm{pH}$ and amplification of spaS (subtilin) and $s p o A$ (subtilosin) genes. In primary screening, among $12 \mathrm{HB}$ isolates, eight strains showed statistically significant highest zones of inhibition $(p \leq 0.05)$ against $E$. coli, K. pneumoniae and $P$. aeruginosa. 16S rRNA sequencing revealed that these isolates belong to Bacillus genus, identified as $B$. tequilensis, B. pumilus, B. xiamenensis, B. subtilis, B. amyloliquefaciens, $B$. safensis, $B$. licheniformis, $B$. altitudinis (Accession numbers: MT186230-MT186237). Secondary screening revealed that among eight isolates, $B$. subtilis and $B$. amyloliquefaciens showed statistically significantly strong inhibition $(p \leq 0.05)$ against all tested pathogens. Antibiotic susceptibility testing revealed that both isolates were resistant to antibiotics and possesses proteolytic, lipolytic and cellulolytic activities. The nature of the compound causing inhibitory activity was found to be proteinaceous and showed stability over a wide range of temperature as well as $\mathrm{pH}$. PCR study confirmed the presence of bacteriocins by successful amplification of important antimicrobial peptide biosynthesis genes spaS and spoA. These results suggest that the HB gut is a home to bacteria that possess antimicrobial activity and important enzymes with antimicrobial potential. To our knowledge, this is the first report demonstrating the antimicrobial potential of bacteria isolated from gut of $\mathrm{HB}$ (A. cerana) against human pathogens.

Keywords: honey bees; gut microbes; antimicrobial activity; B. amyloliquefaciens; B. subtilis; $A$. cerana.

\section{INTRODUCTION}

Increasing antibiotic resistance against bacteria causing serious multiple infections in humans has left scientists with fewer options of successful treatment. There is a need to find new agents having antimicrobial properties [1]. Microorganisms that live and colonize the digestive tracts of animals including insects are known as gut microbiota [2-3]. In insects, the role of gut microbes is directly related to improved ecology, agriculture and medicine. The herbivorous insects, in particular those living in large colonies, for example, honey bees (HB) inhabit diverse ecosystems and microorganisms having symbiotic association with insects also show great diversity. These microbes produce a variety of bioactive secondary

metabolites, which prevent attack of pathogenic bacteria and /predatory species by empowering host immune system and contributing to defensive strategies such as behavioral or mechanical responses [4].

Honey bees play a significant role in human wellbeing both by pollination of important food crops and provision of honey. Globally, more than fifty percent of 115 common food commodities rely on honey bee pollination to produce seeds and fruits. Further, the cost of agricultural goods produced as a result of HB pollination is estimated to be approximately $\$ 15$ billion/year in the U.S. alone. This indicates that colony health of HB hives is very important and management of its deteriorations due to several bee diseases is a serious concern worldwide [5]. For decades, various antibiotics and chemicals have been used to control HB diseases. For example, tetracycline was used to prevent Paenibacillus larvae and Melissococcus plutonius growth to limit American foulbrood (AFB) and European foulbrood, respectively. However, later research proved that both $\mathrm{HB}$ gut microflora and their products pay significant role to prevent and combat bee diseases caused by $P$. larvae [6].

The gut of $\mathrm{HB}$ is a complex environment which supports the growth of great diversity of microbial flora (Streptococcus sp., L. rigidus, Enterobacter sp., Proteus sp., Clostridium sp., Flavobacterium sp., Achromobacter sp., Citrobacter sp., Klebsiella sp., Pseudomonas sp., Bacillus sp., and Gram-negative bacteria). Microbial diversity of HB gut fluctuates depending upon various factors, for example, during the flowering season of rape Wang and coauthors [7] reported the Bacillus group dominant bacteria in HB stomachs. Bacillus group was observed to be the dominant bacteria in HB stomachs [7]. Similarly, gut microbiota of summer and winter HB has been observed to diversify. Studies have shown that the HB gut supports growth of both lactic acid bacteria (LAB) and Fructophilic Lactic Acid Bacteria (FLAB) [8], particularly 
L. kunkeei [9]. LAB prefers glucose and FLAB prefers fructose as a growth substrate. The gut of Slovakian $\mathrm{HB}$ was found to be mainly colonized by anaerobic, rather than aerobic bacteria belonging to Coliforms, Enterococci, Staphylococci, Bacillus sp., Pseudomonas sp., microscopic fungi and yeast [9]. Additionally, a great variety of different microorganisms can be transferred from HB gut to honey [10]. There are reports where honey showed better antibacterial activity compared to antibiotics. Likewise, pure form of honey has proven the best against many serious pathogenic bacteria E. coli, Shigella sp., Salmonella sp., V. cholerae and other Gram -ive as well as Gram +ive microoorganisms. The observed high antibacterial potential of honey is the result of acidity, hydrogen peroxide, osmotic effect and phytochemical factors [11].

Asian HB, Apis cerana Indica F. (Hymenoptera: Apidae), is a social insect and native to Pakistan. Disayathanoowat and coauthors [12] studied the bacterial diversity of midgut of $A$. cerana. Authors isolated aerobic bacteria by culturing on five different media and characterized fifty eight isolates using biochemical tests and 16S rRNA gene sequencing. Two dominant phyla Gamma-proteobacteria and Firmicutes with abundant bacterial species Enterobacter cloacae, Klebsiella oxytoca and $\mathrm{K}$. pneumonia were found. Bacterial isolates were observed to possess protease and lipase activities and some members of Klebsiella showed effective inhibition of AFB disease [12]. Likewise, Sudhagar and coauthors [13] studied the gut colonizing bacteria of A. cerana from India. Authors reported diversified gut microbial communities inhabiting different elevations and observed Bacillus sp. as predominant genus at higher elevation, while Serratia sp., Klebsiella sp. and Enterobacter sp. was dominant in coastal and plain areas. There is established data from other countries on the antibacterial potential of $A$. cerana gut bacteria against various bee diseases [14-15]. Furthermore, various authors reported LAB [16-17] and Bacillus sp. [16] residing in the $\mathrm{HB}$ gut producing bioactive substances with potential to be used as alternatives to antibiotics against human and animal infections [11].

Further, symbiotic relationship of HB with different insects involves the great diversity of microbes, most of which provide nutritional benefit to host. In some bees, for example stingless bee, nest is made up of plantbased complex biomolecules for example, lipids, proteins and cellulose. In order to make bee nest, these complex biomolecules are degraded by hydrolytic enzymes produced by bacteria residing in HB gut. It was reported that most of these isolates have cellulase, protease and lipase activities [18-19], hence also aid in food digestion by these bees [20]. Antimicrobial activities of HB have been reported to be linked with the presence of antimicrobial peptides such as spaS (subtilin) and spoA (subtilosin) [21]. spoA is a circular anionic antimicrobial peptide produced by B. subtilis [22]. spaS is a linear lantibiotic, resembles to nisin, and is commonly used in food preservation [23].

To date, no information exists about the antibacterial potential of bacteria isolated from $A$. cerana gut against human pathogens around the globe. Most of research has focused on HB (preferably A. mellifera) gut bacterial potential to control bee diseases in countries other than Pakistan. In this study, we used a culture dependent method to isolate, identify and characterize aerobic bacteria from the gut of A. cerana. Antibacterial activities of the HB gut isolates against both Gram positive and Gram negative human pathogens were studied. Following that, bacterial proteolytic, lipolytic and cellulolytic activities were analyzed using modification of existing enzyme assays. Preliminary characterization of CFS inhibitory activity was performed by measuring lactic acid concentrations, enzymatic digestion, and stability over a range of temperature, $\mathrm{pH}$ and amplification of spaS (subtilin) and spoA (subtilosin) genes. This study will provide the primary information about cultureable aerobic gut bacteria of $A$. cerana from Lahore, Pakistan as well as their antibacterial and multienzyme potential.

\section{MATERIAL AND METHODS}

\section{Sample collection and dissection}

Honey bees (HB) were collected from three local beekeepers in Lahore, Pakistan and washed with 95\% alcohol before dissection to prevent surface contamination. Whole alimentary canals of bees were dissected aseptically with the help of sterile forceps under a laminar flow cabinet [24]. Dissected parts were kept in sterile $0.85 \%(\mathrm{w} / \mathrm{v})$ saline solution, homogenized and plated within half hour of collection.

\section{Isolation of bacteria and morphological characterization}

Known aliquots of homogenate were spread on brain heart infusion (BHI) agar plates, tryptic soy agar, Lactobacilli MRS agar and incubated for $37-48$ hours at $37^{\circ} \mathrm{C}$ and relative humidity (80\%). Incubation period was extended until visible colonies appeared on plates. Colonies were purified by streaking and re-streaking. Different colonies were selected on the basis of colony morphology, Gram's staining and motility test [25]. 


\section{Biochemical tests and preparation of cell free supernatant (CFS)}

Following morphological characterization and Gram staining, 12 Gram positive HB gut isolates were found to be morphologically different and selected for biochemical characterization. Different biochemical tests such as catalase test, carbohydrate test, voges proskauer test, methyl red test, starch hydrolysis test (glucose, lactose and sucrose) were performed. Cell free supernatants (CFS) were prepared by culturing the $\mathrm{HB}$ gut isolates in nutrient broth for 24-48 hours at $37^{\circ} \mathrm{C}$ and then centrifuged at $6000 \mathrm{rpm}$ for 25 minutes [20]. Supernatants were filter sterilized through $0.22 \mu \mathrm{m}$ filter papers and stored at $-20 \stackrel{\circ}{ } \mathrm{C}$ till further analysis.

\section{Determination of antibacterial activity}

The antibacterial activity of HB gut isolates was determined using two protocols i.e. primary screening and secondary screening.

\section{Primary screening (Cross streak method)}

In primary screening method, all $12 \mathrm{HB}$ gut isolates were tested against five human pathogens Escherichia coli (MN900682), P. aeruginosa (MN900691), K. pneumonia (MN900695), B. licheniformis (MN900686) and B. subtilis (MN900684) using cross streak method]. Briefly, plates were inoculated with single streak of $\mathrm{HB}$ gut isolates and incubated for $24-48$ hours at $37^{\circ} \mathrm{C}$. Bacterial pathogens were streaked at $90^{\circ}$ angle and again incubated. Zone of inhibition (in $\mathrm{mm}$ ) was measured after 24 hours. Experiment was performed in triplicates.

\section{Genomic DNA extraction, PCR and sequencing}

Genomic DNA of HB gut isolates (HB1, HB2, HB5, HB6, HB8, HB9, HB10 and HB12) with significant antibacterial activity was extracted using GeneJET Genomic DNA purification kit [26]. Five $\mu \mathrm{L}$ of genomic DNA was used for gel electrophoresis and sharp bands of DNA were observed under UV trans-illuminator. Polymerase chain reaction (PCR) was performed to amplify the 16S rRNA gene using a Techne thermo cycler (PROGENE) under standard conditions. It was performed in a PCR tube containing 29.5 $\mu \mathrm{L}$ of DNA grade water, $0.5 \mu \mathrm{L}$ of Taq polymerase, $4 \mu \mathrm{L}$ of $\mathrm{MgCl} 2,5 \mu \mathrm{L}$ of $10 \times$ PCR buffer, $5 \mu \mathrm{L}$ of dNTP mixture, $1 \mu \mathrm{L}$ of Forward primer (5'-AGAGTTTGATCCTGGCTCAG-3'), $1 \mu \mathrm{L}$ of reverse primer (5'AAGGAGGTGATGATCCAGCCGCA-3') and $4 \mu \mathrm{l}$ of template DNA using standard conditions. Amplified products were analyzed by gel electrophoresis $(75 \mathrm{~V}, 30 \mathrm{~min})$ on $1.0 \%$ agarose gel and visualized under UV trans-illuminator. Amplified gene fragments were purified and cleaned using GeneJET Genomic DNA extraction kit. Amplified 16S rRNA genes were sent for sequencing to Axile scientific Singapore. The representative sequences obtained were analysed using Chromas Lite software. Corrected sequences were searched using NCBI BLAST to compare with the nearest matched species. These sequences were deposited in the GenBank nucleotide sequence databases (accession numbers MT186230-MT1862307). A phylogenetic tree from 16S rRNA sequence was built with the neighbor joining method using MEGA 10 software and the genetic distance of each strain was determined [26].

\section{Secondary screening (Agar well diffusion method)}

Secondary screening was performed using agar well diffusion method. Nutrient agar plates were prepared and wells of $6 \mathrm{~mm}$ diameter were made using sterilized cork borer. Test cultures were spread on plates uniformly with the help of sterilized cotton swabs. Nutrient broth and rifampicin (Rif-50 $\mu \mathrm{gmL}-1$ ) were used as positive and negative controls respectively. Plates were incubated for 24 hours at $37^{\circ} \mathrm{C}$ and diameter of zones of inhibition $(\mathrm{mm})$ was assessed to measure the antibacterial activity. Inhibition zones greater than $\geq 10 \mathrm{~mm}$ were considered as positive.

\section{Antibiotic susceptibility test}

Using Kerby-Bauer disc diffusion method [27], different antibiotics (ampicillin; Am-50 $\mu \mathrm{gmL}^{-1}$ ), erythromycin; Ery-20 $\mathrm{gmmL}^{-1}$ ) and rifampicin; Rif-50 $\mathrm{ggmL}^{-1}$ ) were used to check the susceptibility pattern of the selected HB gut isolates. The discs were prepared by placing $20 \mu \mathrm{L}$ of antibiotic on disc and drying aseptically in laminar flow. These discs were placed aseptically on media plates inoculated with $\mathrm{HB}$ gut isolates and incubated overnight at $37^{\circ} \mathrm{C}$. On the basis of presence or absence of zones of growth inhibition, $\mathrm{HB}$ gut isolates were considered sensitive/resistant. 


\section{Physiological characterization}

Physiological characterization was performed by studying growth curve and investigating the effect of $\mathrm{pH}$ and temperature on growth of selected $\mathrm{HB}$ gut isolates. For temperature, test tubes were inoculated with $100 \mu \mathrm{L}$ of fresh bacterial culture except for control and incubated overnight at $30,37,40$ and $50^{\circ} \mathrm{C}$. Likewise, for optimum $\mathrm{pH}$ determination, $\mathrm{pH}$ of nutrient broth was adjusted to $4,6,7,8$ and 10 using $1 \mathrm{M} \mathrm{HCl}$ or $1 \mathrm{M}$ $\mathrm{NaOH}$ nutrient broth followed by inoculation as described above and incubation for 24 hours at $37^{\circ} \mathrm{C}$. Growth curve was determined by inoculating autoclaved $250 \mathrm{~mL}$ nutrient broth $(\mathrm{pH}=7)$ with overnight pre-inoculum of selected $\mathrm{HB}$ gut isolates in $500 \mathrm{~mL}$ pre autoclaved Erlenmeyer flask at $250 \mathrm{rpm}$ except for control under sterilized conditions. First optical density was taken at zero-time interval spectrophotometrically. Afterwards, flasks were incubated at $37^{\circ} \mathrm{C}$ in shaking incubator and OD600 was monitored at various time intervals to capture lag, log, stationary and death phase of HB isolates over a 24 hours' time span.

\section{Measurement of proteolytic, lipolytic and cellulolytic activities}

Following slight modifications of method by Rahman and coauthors [28], proteolytic activity was determined using skimmed milk agar specifically. Briefly, selected $\mathrm{HB}$ gut isolates were cultured at $37^{\circ} \mathrm{C}$ with shaking in the production medium comprising of trypticase soy broth (Oxoid Ltd., Basingstoke, UK) having $1 \%$ tryptone. Overnight broth culture was centrifuged and $0.1 \mathrm{~mL}$ supernatant was mixed with $1 \mathrm{~mL}$ azocasein in Tris $-\mathrm{HCl}$ at $37^{\circ} \mathrm{C} .10 \%$ trichloroacetic acid (Sigma, USA) was added to terminate the reaction. It was followed by incubation and centrifugation. The supernatant was mixed with equal volume of $1 \mathrm{M} \mathrm{NaOH}$. OD was then measured at $450 \mathrm{~nm}$ using a microplate reader.

Lipolytic activity was determined using specific tributyrin agar medium following protocol by Kanwar and coauthors [29] with minor modifications. Bacterial isolates were grown in the production medium comprising trypticase soy broth (TSB) supplemented with $1 \%$ olive oil, $1 \%$ yeast extract, and $0.5 \% \mathrm{CaCl}_{2}$. Overnight culture was centrifuged and supernatant was mixed with $0.1 \mathrm{M}$ phosphate buffer. Afterwards, freshly prepared $0.02 \mathrm{M} \mathrm{p}$-nitrophenyl palmitate in isopropanol was added to supernatant at $37^{\circ} \mathrm{C}$ and $175 \times g$ shaking. Ethanol $(0.1 \mathrm{~mL}$ of $90 \%)$ was added to stop the reaction and absorbance was measured at $410 \mathrm{~nm}$. p-nitrophenol was used as standard to prepare the calibration curve [30].

Following modifications of method by Liang and coauthors [31], cellulolytic activity was determined using carboxymethyl cellulose (CMC) agar specifically for this purpose. Briefly, both bacterial isolates were grown in the production medium ( $\mathrm{pH} 7.0$ ) made of TSB, $2 \% \mathrm{CMC}$, and $1 \%$ yeast extract. Overnight culture was centrifuged and supernatant was mixed with $1 \% \mathrm{CMC}$ in $0.1 \mathrm{M}$ phosphate buffer for $30 \mathrm{~min}$. The reaction was stopped by adding DNS reagent (1\% (w/v) 3,5-dinitrosallicylic acid, $2 \mathrm{M} \mathrm{NaOH}$ and sodium potassium tartrate followed by incubation for $15 \mathrm{~min}$ at $100^{\circ} \mathrm{C}$. OD was measured at $540 \mathrm{~nm}$. Glucose was used as standard to prepare the calibration curve. Experiments were performed in triplicates.

\section{Preliminary characterization of antibacterial compounds}

\section{Determination of lactic acid concentrations}

Following manufacturer's protocol, concentrations of D-lactic acid/L-lactic acid were measured in the CFS of both isolates using D/L-lactic acid test kit (Roche Boehringer, Germany). Obtained data were processed using equations provided in protocol to correctly measure the concentration of each acid (D/Llactic acid) in sample.

\section{Enzymatic digestion of antibacterial compound}

In order to assess the nature of the antibacterial compound that causes growth inhibition of tested pathogens, CFS of both isolates was treated with seven enzymes catalase, proteinase $\mathrm{K}$, pepsin, trypsin, chymotrypsin, lipase and protease (Sigma) overnight. Briefly, $200 \mu \mathrm{l}$ aliquots of the CFS were mixed with equal quantity of enzymes for 24 hours at incubation temperature $\left(50,70\right.$ and $\left.90^{\circ} \mathrm{C}\right)$ and $\mathrm{pH}(4,6,8$ and 10) appropriate for optimal activity of respective enzyme. Two controls i.e., (i) enzyme with sterile MRS media, and (ii) enzyme diluent with CFS were used in parallel. After incubation period of 24 hours, $\mathrm{pH}$ of all samples was neutralized to $6.0+/-0.2$ and antibacterial activity was measured compared to indicator strain $P$. aeruginosa using agar well diffusion assays. 
Amplification of subtilin and subtilosin genes

To determine whether $B$. subtilis and $B$. amyloquefaciens possess bacteriocins responsible for antibacterial activity, two genes i.e., subtilin (spaS) and subtilosin $(s b o A)$ were amplified using previously reported specific primers [spaSFwd -AAGTTCGATGATTTCGATTTGGATG, spaSRev AGTTACAAGTTAGTGTTTGAAGGAA [32]; sboAFwd-CGCAAGTAGTCGATTTCTAACA, sboARev CGCAAGTAGTCGATTTCTAACA [23]. Master mix having genomic DNA of both isolates, primers, nucleotides, buffer and Taq polymerase was prepared. PCR was performed following denaturation for $30 \mathrm{~s}$ at $95^{\circ} \mathrm{C}$, annealing for $30 \mathrm{~s}$ at $54^{\circ} \mathrm{C}(\mathrm{spaS})$ or $53^{\circ} \mathrm{C}(\mathrm{sboA})$, and elongation for $1 \mathrm{~min}$ at $65^{\circ} \mathrm{C}$ for a total of 35 cycles. Obtained sequences were analysed using chromas lite and deposited at GenBank (MT490214) for subtilis and (MT490213, MT495613) for subtilosin of B. amyloliquefaciens and B. subtilis respectively.

\section{Statistical analysis}

All experiments were performed in triplicates. The mean and standard deviation of zones of inhibition were calculated. One way analysis of variance (one-way ANOVA) followed by post- hoc Turkey's test was performed using SPSS software (Statistical Package for Social Sciences) version 21 Chicago, IL, USA to determine significant differences at $\mathrm{P} \leq 0.05$ among different groups.

\section{RESULTS}

\section{Isolation and morphological characterization of HB gut bacteria}

A total of twelve colonies (HB1-HB12) were found to be morphologically different from other colonies on the surface of $\mathrm{BHI}$ agar. Five colonies (HB3, HB4, HB7, HB9 and HB12) were irregular in shape and seven (HB1, HB2, HB5, HB6, HB8, HB10, HB11) were circular. All colonies were opaque and white in color. Gram's staining revealed that all isolates (HB1-HB12) were Gram-positive, rod shape and motile (Table S1). Biochemical tests revealed that only two isolates (HB2 and HB7) were catalase and voges proskauer negative. All isolates fermented three sugars (glucose, lactose and sucrose) except for one isolate (HB11), which was unable to ferment lactose. All isolates were able to hydrolyze starch and only two $\mathrm{HB}$ isolates (HB2 and HB7) were negative for methyl red (Table S2).

\section{Antibacterial activity via primary screening (Cross streak method)}

Cross streak method was used to check the antibacterial activity of all 12 Gram-positive, motile HB gut isolates against $P$. aeruginosa, $E$. coli, B. licheniformis, $K$. pneumoniae and $B$. subtilis. Among twelve $\mathrm{HB}$ isolates, gut isolates HB1 and HB12 showed significantly higher zones of inhibition (ZI; 7-11mm; $p \leq 0.05$ ) against E. coli. Isolates HB5 and HB6 showed highest ZI $(7-8 \mathrm{~mm} ; \mathrm{p} \leq 0.05)$ against $K$. pneumoniae and both HB9, HB10 showed highest $\mathrm{ZI}$ against $P$. aeruginosa $(8 \pm 0.57 ; \mathrm{p} \leq 0.05)$. Eight HB gut isolates showed significant inhibitory activity against both Gram-positive and Gram-negative pathogens (Figure. 1a, b), hence subjected to $16 \mathrm{~S}$ rRNA sequencing and secondary screening.

a)
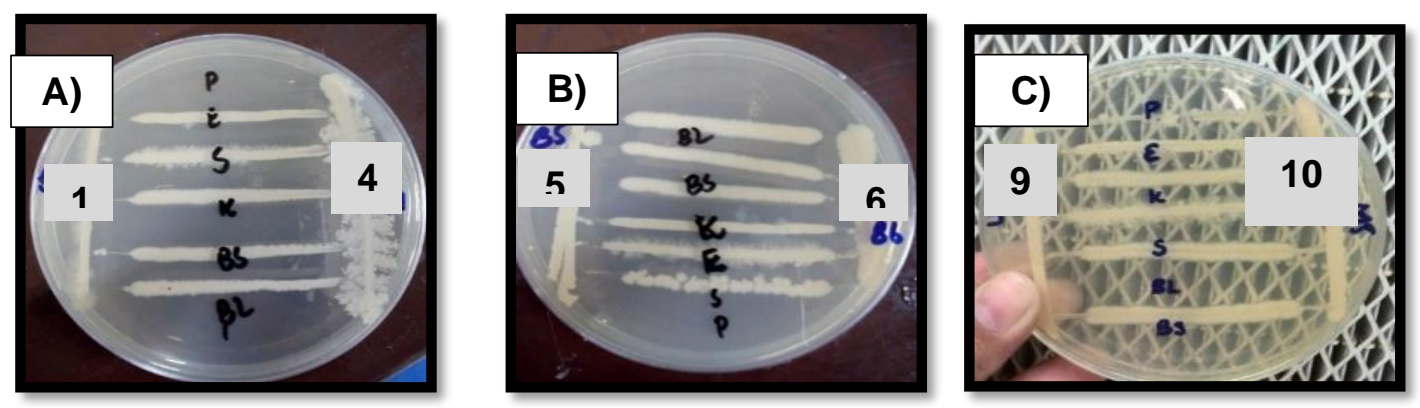

Figure 1a. Antimicrobial activity of some honey bee $(\mathrm{HB})$ gut isolates against human pathogens using cross streak method (A) HB gut isolates HB1 and HB4 against pathogens (B) Inhibition by isolate HB5 and HB6 (C) Inhibition of pathogens by isolates HB5 and HB6. P, P. aeruginosa; E, E. coli; B.L, B. licheniformis; S, B. subtilis; K, K. pneumonia. 
b)

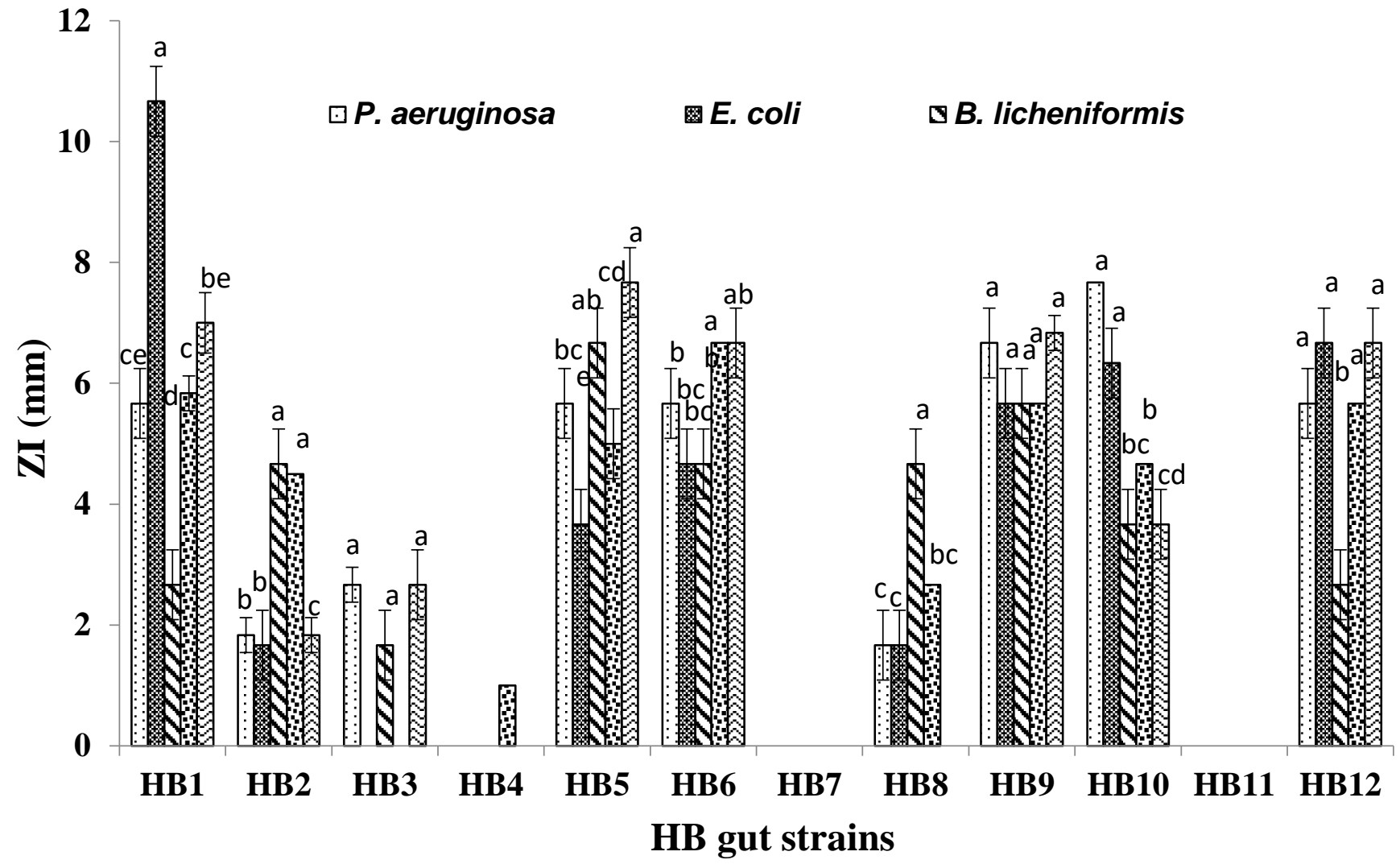

Figure 1b. Antimicrobial activity of twelve honey bee (HB) gut isolates (HB1-HB12) against five human pathogens $(P$. aeruginosa, E. coli, B. licheniformis, Salmonella sp., K. pneumoniae) using cross streak method. Among twelve isolates, eight HB gut isolates (HB1, HB2, HB5, HB6, HB8, HB9, HB10, HB12) showed significant inhibitory activity against both Gram-positive and Gram-negative pathogens. One-way analysis of variance (ANOVA) with post hoc turkey test was used to determine the level of significance. Bars with different superscripts are significantly different at $P \leq 0.05$.

\section{S rRNA gene sequencing}

Eight HB gut isolates (HB1, HB2, HB5, HB6, HB8, HB9, HB10 and HB12) were identified upto species level using partial 16S rRNA gene sequence analysis. Comparison of HB gut isolates with sequences from BLAST programme at National Centre for Biotechnology Information (NCBI) database revealed that eight gut isolates belong to the evolutionary clade of genus Bacillus. These isolates were $B$. subtilis (HB1, MT186233), $B$. xiamenensis (HB2, MT186232), B. altitudinis (HB5, MT186237). B. safensis (HB6, MT186235), B. licheniformis (HB8, MT186236), B. amyloliquefaciens (HB9, MT186234), B. tequilensis (HB10, MT186230) and B. pumilus (HB12, MT186231) (Figure 2). 


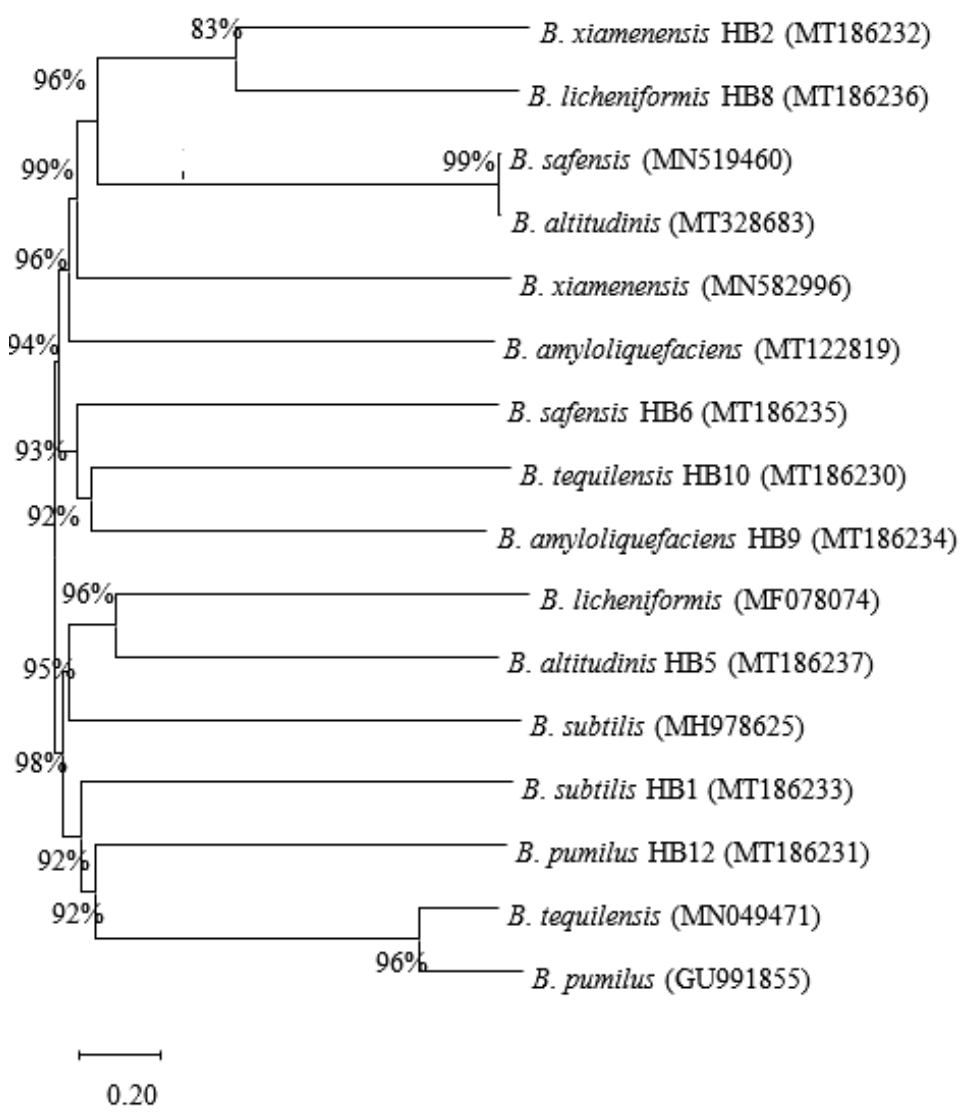

Figure 2. Phylogenetic study of $16 \mathrm{~S}$ rRNA partial genome sequences of promising honey bee (HB) bacteria (HB1, HB2, HB5, HB6, HB8, HB9, HB10, HB12). Bacteria isolated from gut of HB were identified using 16S rRNA partial gene sequenicng and compared with the sequences from National Centre for Biotechnology Information (NCBI). The analysis was conducted with MEGA10 using neighbor-joining method and the genetic distance of each strain was determined.

\section{Antibacterial activity (agar well diffusion method)}

Secondary screening of eight identified HB gut isolates (HB1, HB2, HB5, HB6, HB8, HB9, HB10 and HB12) was performed using agar well diffusion method. B. subtilis (HB1) and B. amyloliquefaciens (HB9) showed highest inhibition against all pathogens and their greatest inhibitory activity was against $E$. coli (Zl; $13 \pm 0.577 \mathrm{~mm} ; 14 \pm 0.330, \mathrm{p} \leq 0.05$ ). B. altitudinis (HB5) showed significant inhibitory activity against $E$. coli and $B$. licheniformis $(6-8 \mathrm{~mm} ; \mathrm{p}=0.0161)$ only while $B$. safensis $(\mathrm{HB} 6)$ showed highly significant inhibition against $K$. pneumoniae $(12 \mathrm{~mm} ; \mathrm{p} \leq 0.01)$ (Figure 3 ). Additionally, $B$. subtilis (HB1) and $B$. amyloliquefaciens (HB9) were the only isolates able to inhibit growth of $P$. aeruginosa $(8-11 \mathrm{~mm} ; \mathrm{p} \leq 0.05)$. This led us to select $B$. subtilis (HB1) and B. amyloliquefaciens (HB9) for further antibiotic susceptibility testing, physiological characterization, extracellular enzyme assays and gene study. 


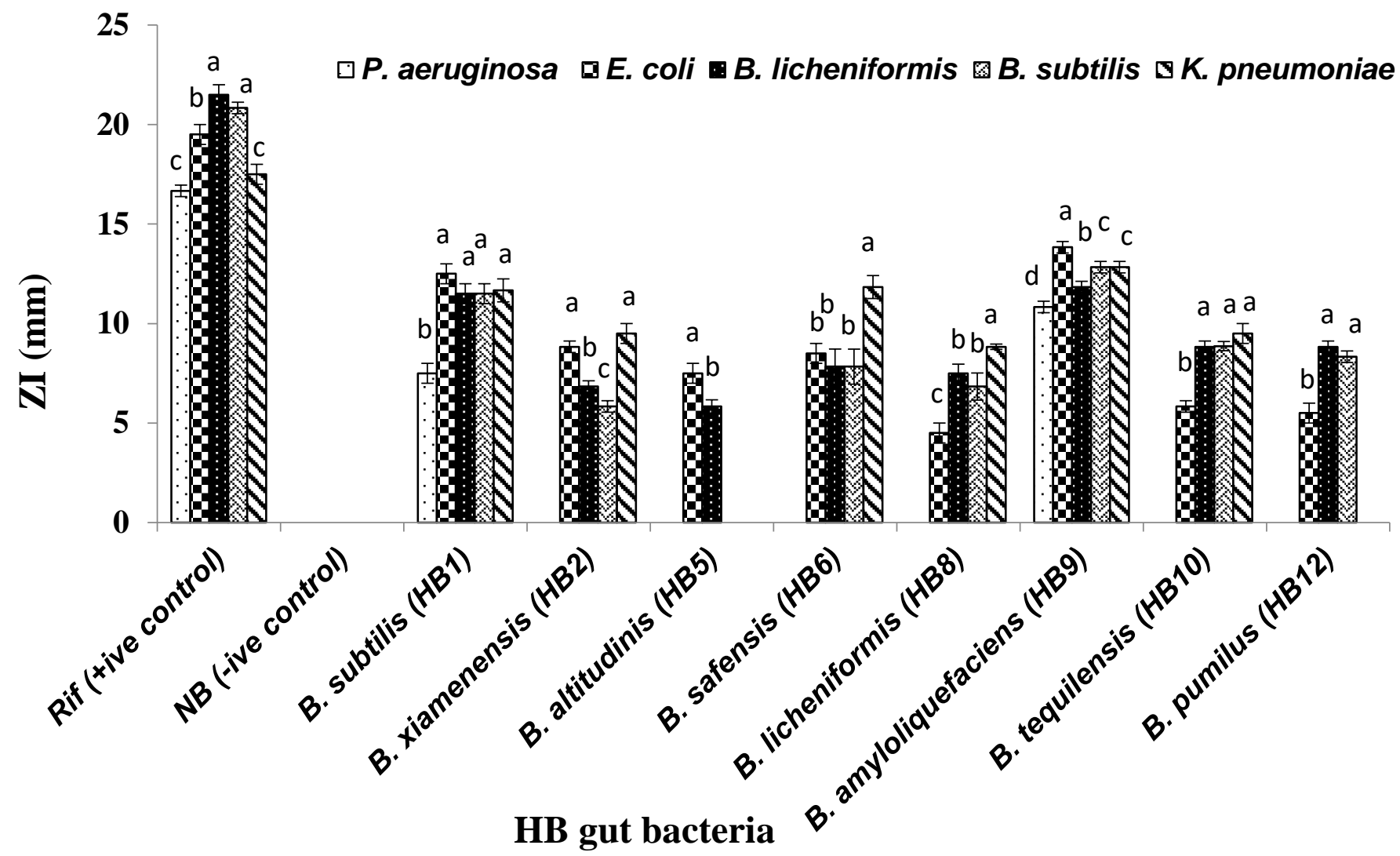

Figure 3. Antimicrobial activity of eight honey bee (HB) gut isolates (HB1, HB2, HB5, HB6, HB8, HB9, HB10, HB12) against five human pathogens ( $P$. aeruginosa, E. coli, B. licheniformis, Salmonella sp., K. pneumoniae) using agar well diffusion method. One-way analysis of variance (ANOVA) with post hoc Tukey test was used to determine the level of significance. Bars with different superscripts are significantly different at $P \leq 0.05$.

\section{Antibiotic susceptibility profile}

Both isolates [B. subtilis (HB1) and B. amyloliquefaciens (HB9)] showed sensitivity against the three antibiotics (ampicillin, erythromycin and rifampicin) used in this study. Both isolates were more susceptible to rifampicin, $(\mathrm{Zl}=5-6 \mathrm{~mm})$ and less susceptible to erythromycin and ampicillin ( $\mathrm{Zl}=3-4 \mathrm{~mm})$ (Figure 4).

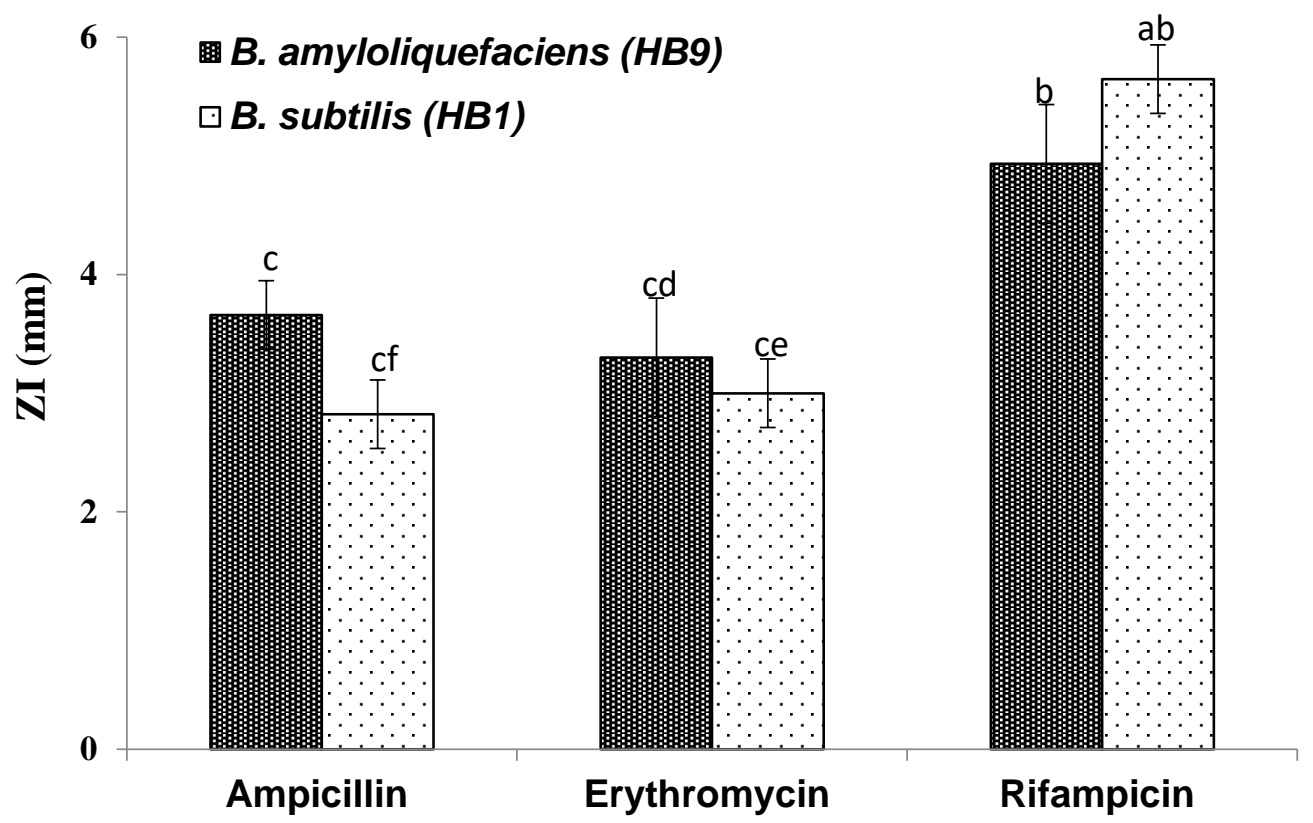

Figure 4. Antibiotic susceptibility profile of honey bee (HB) gut isolates $B$. amyloliquefaciens (HB9) and B. subtilis (HB1). Three antibiotics rifampicin $\left(50 \mu \mathrm{gmL}^{-1}\right)$, ampicillin $\left(50 \mathrm{\mu gmL}^{-1}\right)$ and erythromycin $\left(20 \mathrm{\mu gmL}^{-1}\right)$ were used. One-way analysis of variance (ANOVA) with post hoc Tukey test was used to determine the level of significance. Bars with different superscripts are significantly different at $P \leq 0.05$. 


\section{Growth curve study, $\mathrm{pH}$ and temperature effect}

Growth curve of isolates indicated that both B. subtilis (HB1) and B. amyloliquefaciens (HB9) showed lag phase of 1 hour and log phase of 3 hours. Afterwards, stationary phase lasted for 3-4 hours in both isolates. Following stationary phase, death phase was observed (Figure 5). B. subtilis (HB1) and $B$. amyloliquefaciens (HB9) were characterized for their optimum temperature and $\mathrm{pH}$. It was observed that both isolates showed best growth at temperature $37^{\circ} \mathrm{C}$ and $\mathrm{pH} 7$ (Figure 6).

a)

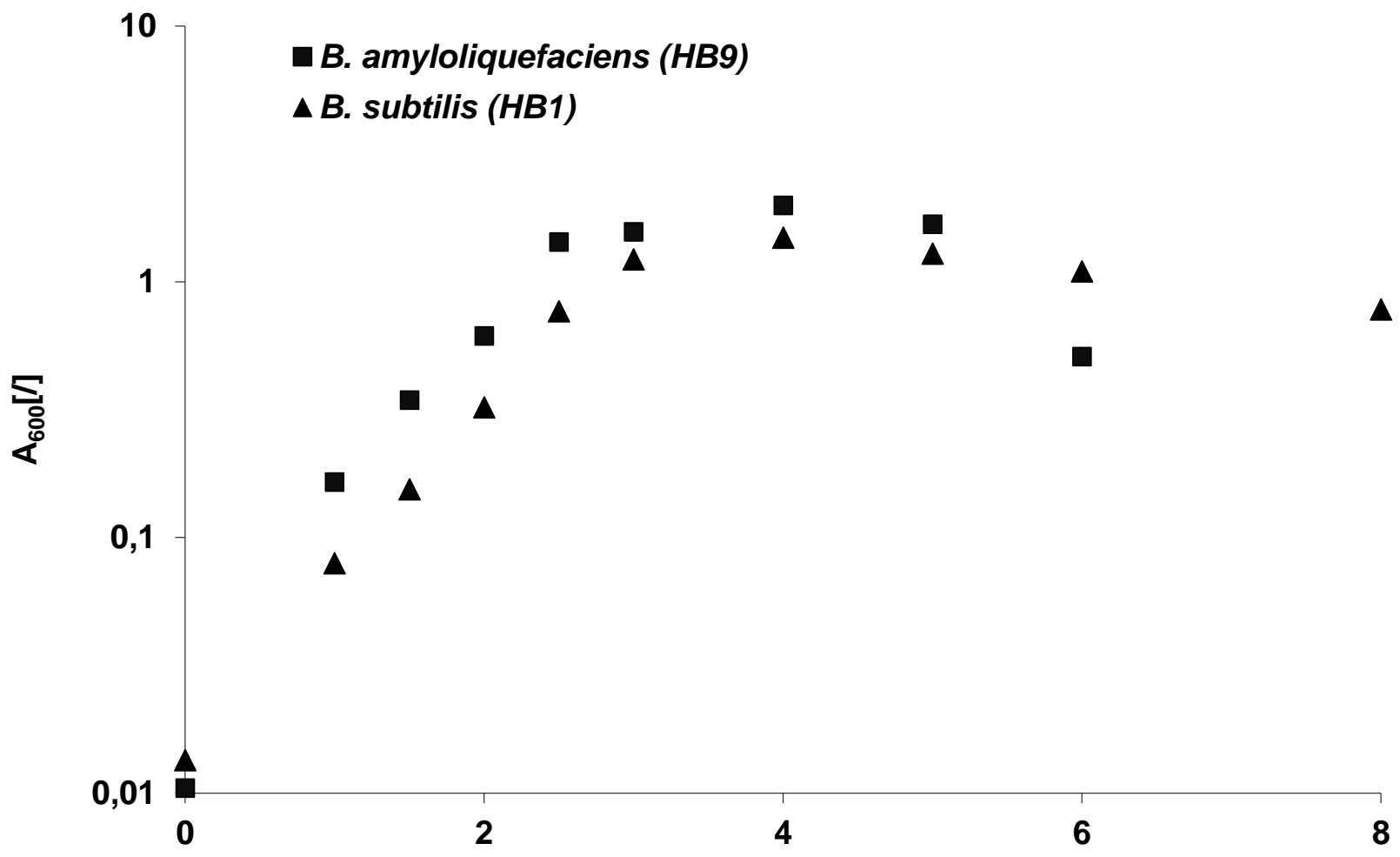

b)

\section{Time [hours]}
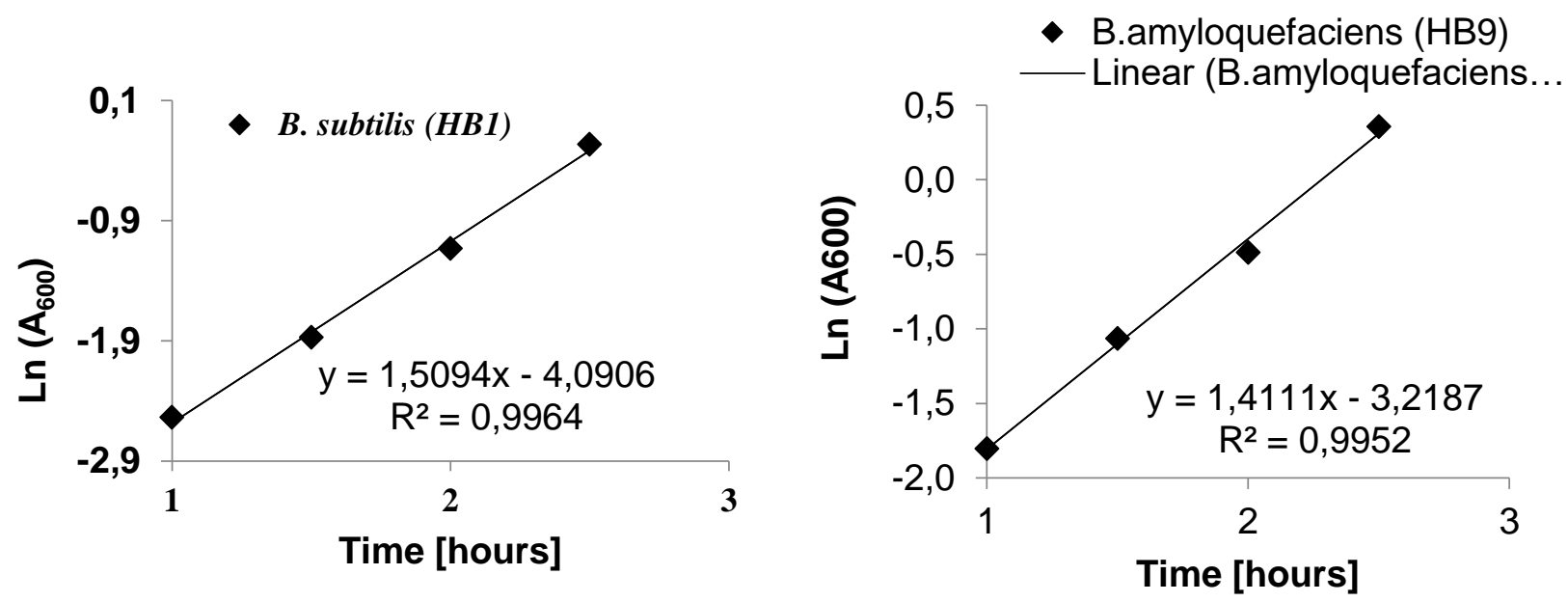

Figure 5. Growth curve of two promising honey bee (HB) gut isolates $B$. subtilis (HB1) and B. amyloliquefaciens (HB9). a). Bacterial growth was determined by $\mathrm{OD}_{600}$. Data were obtained from the average of three independent experiments b). Specific growth rate of two isolates $B$. subtilis (HB1) and B. amyloliquefaciens (HB9). It was measured by taking OD measurements at fixed intervals and plotting the growth with $\operatorname{Ln}(\mathrm{OD})$ at the $y$-axis (exponential phase) and time at $x$ axis to find linear curve from 3-4 points. 
a)

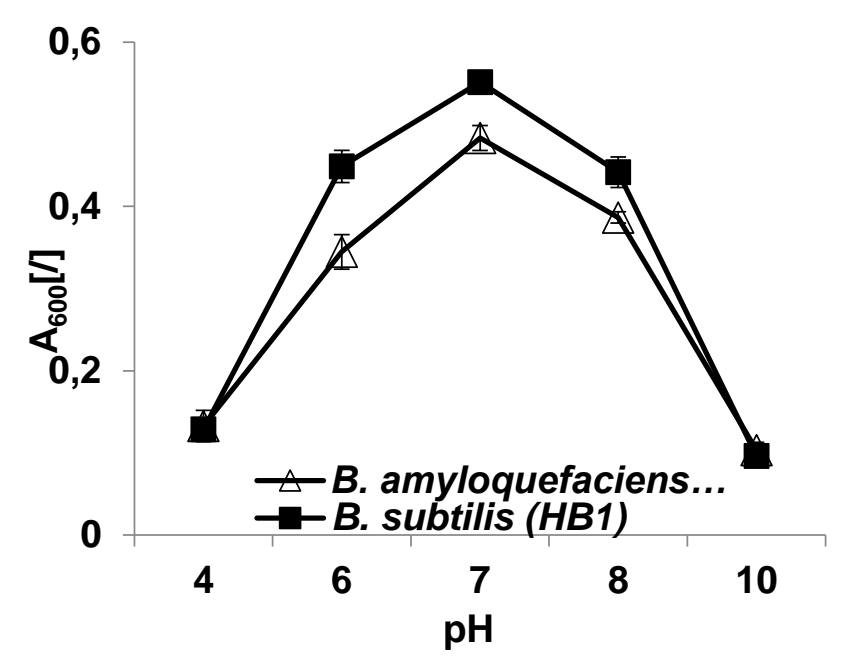

b)

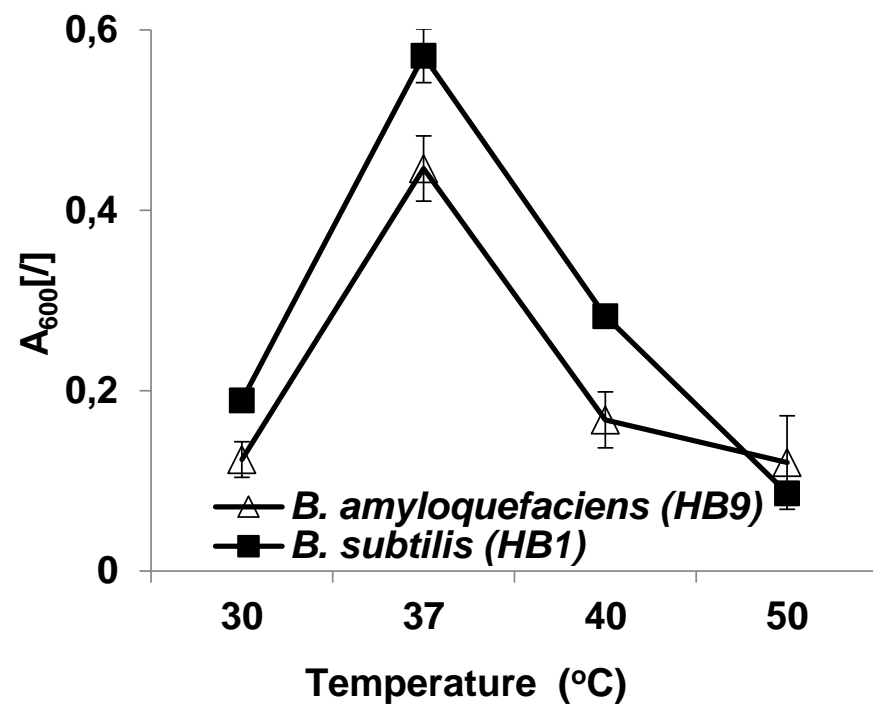

Figure 6. Effect of $\mathrm{pH}$ and temperature on two promising honey bee (HB) gut isolates $B$. subtilis (HB1) and $B$. amyloliquefaciens (HB9). Bacteria were grown in $\mathrm{LB}$ medium at a) various $\mathrm{pH}(4,6,7,8$ and 10) and b) temperatures $\left(30,37,40\right.$ and $\left.50^{\circ} \mathrm{C}\right) . \mathrm{OD}_{600}$ indicated maximum growth at $\mathrm{pH} 7$ and temperature $37^{\circ} \mathrm{C}$. Results were expressed as Mean \pm SD. Experiments were performed in triplicates $(n=3)$.

\section{Extracellular enzyme activities of bacterial isolates}

Cellulase, protease and lipase activities of both isolates $B$. subtilis (HB1) and B. amyloliquefaciens (HB9) revealed that they possess all the three enzyme activities (Table 1). Briefly, cellulolytic activities were found to be high for both $B$. subtilis (HB1) and $B$. amyloliquefaciens (HB9) (ranging from 0.70 to $0.75 \mathrm{U} / \mathrm{mL}$ ) (Table 1). B. amyloliquefaciens (HB9) showed the highest proteolytic activity $(2.48 \mathrm{U} / \mathrm{mL}$ ), while the lowest was found from $B$. subtilis $(1.20 \mathrm{U} / \mathrm{mL}$ ). Lastly, B. subtilis (HB1) and B. amyloliquefaciens (HB9) showed almost equal lipolytic activity $(0.80-0.82 \mathrm{U} / \mathrm{mL})$ (Table 1$)$.

Table 1. Extracellular enzyme activity of two promising HB gut bacteria

\section{Bacterial isolates}

Extracellular enzyme activity $(\mathrm{U} / \mathrm{ml})$

\begin{tabular}{lccc}
\cline { 2 - 4 } & Proteolytic & Lipolytic & Cellulolytic \\
\hline B. subtilis (HB1) & $1.20 \pm 0.05$ & $0.82 \pm 0.04$ & $0.70 \pm 0.01$ \\
B. amyloliquefaciens (HB9) & $2.48 \pm 0.06$ & $0.80 \pm 0.02$ & $0.75 \pm 0.02$
\end{tabular}

\section{Measurement of lactic acid concentrations}

Both isolates i.e., B. subtilis (HB1) and B. amyloliquefaciens (HB9) produced very small amount of Dand L-lactic acid. Results showed total production of $0.17 \mathrm{~g} \mathrm{I}^{-1} \mathrm{D}$-lactic acid per sample, which was equal to blank. Concentrations of L-lactic acid was averaged to $2.23-2.25 \mathrm{~g} \mathrm{I}^{-1}$ in both isolates respectively, which was higher from $0.16 \mathrm{~g} \mathrm{l}^{-1}$ concentration of blank (Table 2).

Table 2. D- and L-lactic acid concentration in cell-free supernatant

\begin{tabular}{lllll}
\hline Sample & $\boldsymbol{\Delta} \boldsymbol{A}_{\mathbf{D}}$ & [D-Lactic acid] $\left(\mathbf{g ~ l}^{-1}\right)$ & $\boldsymbol{\Delta} \boldsymbol{A}_{\mathbf{L}}$ & [L-Lactic acid] $\left(\mathbf{g ~ I}^{-1}\right)$ \\
\hline Blank & $0.05+/-0.00$ & $0.19+/-0.01$ & $0.05+/-0.00$ & $0.16+/-0.01$ \\
B. subtilis (HB1) & $0.05+/-0.00$ & $0.17+/-0.09$ & $0.68+/-0.01$ & $2.25+/-0.02$ \\
B. amyloliquefaciens (HB9) & $0.05+/-0.00$ & $0.17+/-0.02$ & $0.68+/-0.00$ & $2.23+/-0.03$ \\
\hline
\end{tabular}




\section{Enzyme digestion and effect of temperature and $\mathrm{pH}$ on antibacterial activity}

Table 3 summarizes the results of CFS treatment with seven enzymes. Almost complete loss of activity in the presence of proteinase $\mathrm{K}$ and pepsin, and significantly decreased activity upon treatment with trypsin and chymotrypsin was observed, thus indicating proteniacious nature of antibacterial activity. Temperature and $\mathrm{pH}$ also had no effect on antibacterial activity of the studied CFS (Table 4).

Table 3. Effect of enzymatic digestion on antimicrobial activity

\begin{tabular}{|c|c|c|c|c|}
\hline \multirow[t]{2}{*}{ Enzyme } & \multirow{2}{*}{$\begin{array}{c}\text { Enzyme } \\
\text { concentration } \\
\left(\mathrm{mg} \mathrm{mL}^{-1}\right)\end{array}$} & \multirow[t]{2}{*}{ Enzyme diluent } & \multicolumn{2}{|c|}{ Zone of inhibition (mm) } \\
\hline & & & $\begin{array}{l}\text { B. } \\
\text { (HB1) }\end{array}$ & B. amyloliquefaciens (HB9) \\
\hline Trypsin & 20 & $1 \mathrm{mmol} \mathrm{I}^{-1} \mathrm{HCl}$ & $3.0+/-0.26$ & $3.0+/-0.26$ \\
\hline Pepsin & 10 & $10 \mathrm{mmol} \mathrm{I}^{-1} \mathrm{HCl}$ & $3.0+/-0.50$ & $3.0+/-0.50$ \\
\hline Proteinase $\mathrm{K}$ & 10 & $\mathrm{ddH}_{2} \mathrm{O}$ & $2.0+/-0.29$ & $3.0+/-0.29$ \\
\hline Chymotrypsin & 10 & $1 \mathrm{mmol} \mathrm{I}-1 \mathrm{HCl}$ & $5.0+/-0.58$ & $5.0+/-0.58$ \\
\hline Catalase & 10 & $50 \mathrm{mmol} \mathrm{I}^{-1} \mathrm{Kpi}(\mathrm{pH} 7)$ & $12.0+/-0.58$ & $11.0+/-0.58$ \\
\hline Lipase & 20 & $\mathrm{ddH}_{2} \mathrm{O}$ & $11.0+/-0.76$ & $11.0+/-0.76$ \\
\hline Protease & 10 & $\mathrm{ddH}_{2} \mathrm{O}$ & $6.0+/-0.29$ & $6.0+/-0.29$ \\
\hline
\end{tabular}

Table 4. Effect of temperature and $\mathrm{pH}$ on antimicrobial activity

\begin{tabular}{|c|c|c|c|c|}
\hline \multirow[t]{2}{*}{ Temperature $\left({ }^{\circ} \mathrm{C}\right)$} & \multirow[t]{2}{*}{$\mathrm{pH}$} & \multirow{2}{*}{$\begin{array}{l}\text { Exposure time } \\
\text { (min) }\end{array}$} & \multicolumn{2}{|c|}{ Antimicrobial activity } \\
\hline & & & B. subtilis (HB1) & B. amyloliquefaciens (HB9) \\
\hline \multirow[t]{2}{*}{40} & 4 & 10 & + & + \\
\hline & & 60 & + & + \\
\hline \multirow[t]{2}{*}{60} & 6 & 10 & + & + \\
\hline & & 60 & + & + \\
\hline \multirow[t]{2}{*}{80} & 8 & 10 & + & + \\
\hline & & 60 & + & + \\
\hline \multirow[t]{2}{*}{100} & 10 & 10 & + & + \\
\hline & & 60 & + & + \\
\hline
\end{tabular}

\section{Genetic study of bacteriocins}

PCR study showed that both $B$. subtilis (HB1) and B. amyloliquefaciens (HB9) were positive for the functional gene-encoding subtilosin (spoA). BLAST study of DNA sequence of amplified PCR product from both isolates showed $98-100 \%$ similarity with subtilosin A of $B$. subtilis (WP_087992738.1). However, spaS gene encoding subtilin protein was only successfully amplified in $B$. subtilis (HB1) having $83 \%$ homology with subtilin of B. subtilis (QIR30939.1).

\section{DISCUSSION}

Resistance of bacteria to antibiotics is emerging rapidly worldwide which is endangering the efficiency of antibiotics. Antibiotic resistance has become a global burden to health sector [33]. This study was carried out to study promising bacteria from gut of honeybees which can produce novel bioactive compounds as alternative to antibiotics. Using culture based methods, white, rod shape bacteria were selected and purified on nutrient agar. The purified bacteria were further characterized morphologically and biochemically. Morphological identification showed variations in colony appearance, opacity, margin and elevation. Biochemical characterization revealed that almost all bacteria had ability to ferment carbohydrates and hydrolyze the starch. These biochemical tests were comparable to the findings by Audisio and coauthors [34], who reported Gram positive rod shaped bacteria from HB gut with ability to ferment carbohydrates and 
hydrolyze starch. Similarly findings were also reported by Audisio [35], who isolated Gram positive, motile and catalase positive HB gut.

Antibacterial activity of HB gut bacteria using cross streak method revealed that these bacteria have the tendency to inhibit the pathogens. HB gut bacteria exhibited broad spectrum antibacterial activity with variable inhibition zones against $E$. coli, B. licheniformis, $P$. aeruginosa, $K$. pneumoniae and $B$. subtilis. The antibacterial activity of HB gut isolates against both Gram positive and Gram negative bacteria observed in this study might be due to the bactericidal effect of protease sensitive bacteriocin like substances, production of hydrogen peroxide and organic acids [36]. However, mechanism of antibacterial action may have other attributions. For example, Janashia and coauthors [37] reported that antibacterial activity of HB LAB is due to synergistic action of several other secondary metabolites in addition to bacteriocins. Likewise, Yoshiyama and coauthors [38] analysed the transcription level patterns of antibacterial peptide genes from LAB of HB gut and verified these as immune activators.

16S rRNA sequencing of eight promising HB gut strains revealed that all strains displayed closest similarity with phylum Firmicutes, genus Bacillus. Previously, Yoshiyama and Kimura [15] assessed the bacterial diversity in the digestive tract of the $A$. cerana japonica, Japanese honeybee, using 16S rRNA gene sequencing and histological studies. Authors reported that seven bacteria with strong inhibitory activity against $P$. larvae belonged to genus Bacillus. In another study, Pomastowski and coauthors [14] also made similar observations. They isolated the bacterial strains from honey and 16S rRNA sequencing revealed the isolate as $B$. tequilensis (NR 104919). Likewise, Agbagwa and coauthors [39] reported antibacterial potential of Bacillus species alongwith antibiotics residues from branded and unbranded honey samples, Nigeria.

Agar well diffusion assay of eight promising HB gut strains was studied using CFS against $E$. coli, $K$. pneumoniae, $P$. aeruginosa, $B$. licheniformis and $B$. subtilis. Only two isolates $B$. amyloliquefaciens and $B$. subtilis inhibited the growth of all tested pathogens. Similar findings were reported by Hasali and coauthors [40], who studied antibacterial activity of HB microbiota using agar well diffusion method and found excellent inhibitory activity of HB microbiota against different pathogens; S. epidermidis, B. subtilis, $P$. aeruginosa, $E$. coli, S. typhimurium, S. aureus and L. monocytogenes. Likewise, Kacaniova and coauthors [6] investigated the antibacterial activity of HB gut bacteria against $P$. larvae. Authors observed that $L$. gasseri and $L$. amylovorus showed strongest antibacterial activity against $P$. larvae compared to $L$. fructivorans which had least antibacterial activity. In contrast, Janashia and coauthors [37] reported that none of his studied HB gut isolates showed any antibacterial activity against tested pathogens.

Following antibacterial activity and 16S rRNA sequencing antibiotic susceptibility profile of $B$. amyloliquefaciens and $B$. subtilis was performed. It was observed that both isolates showed less susceptibility to rifampicin compared to ampicillin and erythromycin. Between two isolates, $B$. subtilis was more sensitive towards tested antibiotics compared to the $B$. amyloliquefaciens. Similar results were also reported by Kacaniova and coauthors [6] in which antibiotic resistance of HB gut bacteria was checked against ciprofloxacin, levofloxacin and gentamicin. Their findings revealed that isolated Gram positive bacteria were sensitive to all aforementioned antibiotics. In another study by Gharehyakheh and coauthors [41], susceptibility of HB gut bacteria was checked against commercially available antibiotics (chloramphenicol, kanamycin, erythromycin, penicillin, streptomycin and amoxicillin). Results showed that all isolates showed susceptibility for tested antibiotics with maximum inhibition against chloramphenicol.

When we looked at the optimum growth conditions of the two isolates i.e., B. amyloliquefaciens and $B$. subtilis, we found that growth was optimum at $37^{\circ} \mathrm{C}$ temperature and $\mathrm{pH}$. This is similar to the results shown by Albaridi [42]. They observed that HB gut bacteria showed best growth at $\mathrm{pH}$ range of 6.5-7.5. Raghavan and coauthors [43] observed the growth of HB gut bacteria at acidic and basic environment, and different temperature range $\left(30-40{ }^{\circ} \mathrm{C}\right)$. Their findings revealed that most stains were resistant to acidic $\mathrm{pH}$, with optimum growth at $\mathrm{pH} 7$ and temperature $37^{\circ} \mathrm{C}$.

Enzyme assays were performed to screen hydrolytic enzymes. We observed that both isolates possess cellulose, protease and lipase. Enzymes produced by the bacterial isolates might be involved in the food digestion and breakdown of complex biomolecules for example, carbohydrates and proteins involved in bee nest formation [19]. Insects perform symbiotic relationships with various microorganisms. Symbiotic bacteria of insects not only benefit the host nutritionally [44], but also play important in degradation of nest products and other pathogens by producing various enzymes [20].

To confirm the nature of antibacterial activity, a series of preliminary tests were conducted. Absence of $\mathrm{D} / \mathrm{L}$ lactic acid and sensitivity of CFS towards protein degrading enzymes suggested its proteniacious nature. Likewise, stability and antibacterial activity at high temperature and $\mathrm{pH}$ stresses is in agreement with the 
findings observed by Sharma and coauthors [45], who attributed the stability of Bacillus bacteriocins to the presence of unusual amino acids present in CFS. These observations suggest that CFS of both Bacilli isolates possess antibacterial substances belonging to class of bacteriocins.

Presence of bacteriocins in CFS was confirmed by successful amplification of $s b o A$ and spaS genes. Data revealed that CFS of both bacteria possesses subtilosin (encoded by $s b o A$ gene), similar to bacteriocin. Presence of subtilosin protein was reported both in B. subtilis [46] and B. amyloliquefaciens [47], previously. In fact, presence of subtilosin protein in $B$. amyloliquefaciens might correspond to the fact that both isolates show close similarity with respect to their 16S rRNA regions and 16S-23S internal transcribed spacer regions [48]. B. amyloliquefaciens is diverge species compared to $B$. subtilis and its closely related $B$. atrophaeus. Albano and coauthors [49] did transcriptional profiling of $B$. subtilis and confirmed Rok protein orthologue (encoded by roc gene) in $B$. amyloliquefaciens that might have transferred from $B$. subtilis via horizontal gene transfer. Subtilin protein amplification in $B$. subtilis only in this study is in agreement with previously published findings by Abriouel and coauthors [46]. There are several other studies where authors reported that Bacillus species produce a diverse range of bacteriocins such as ericin $A$, subtilin, ericin $S$, cerein 7A, coagulin and cerein 7B etc. These bacteriocins have been observed to show antibacterial activity against food-borne pathogens, and potential in biomedical industry [50]. Similarly, Shelburne and coauthors [51] studied the antibacterial activity of subtilosin in detail and observed broad spectrum activity of bacteriocins against majority of microbes except for encapsulated ones. However, these findings were contradicted by Abriouel and coauthors [46], who suggested subtilosin as an ideal bacteriocin to treat bacterial vaginosis without any harm to healthy microbes.

This study provides evidence that bacteriocins might be important candidates for food preservation. In a study by Burkard and coauthors [52], similar to nisin, subtilin and subtilosin A have been found quite effective against $L$. monocytogenes. Suwanjinda and coauthors [53] used PCR to determine the presence of bacteriocins such as nisin, pediocin and enterocin A in lactic acid bacteria isolated from traditional Thai fermented foods. Although, commercially available nisin is mainly used in food applications, there is continuous need to develop new lantibiotics and unmodified bacteriocins. Problems such as bacteriocins instability in certain foods/environments and low production levels need to be properly addressed. However this needs further investigation by the food industry because range of activity by bacteriocins is often specific and limited.

\section{CONCLUSION}

It can be concluded from the present study that microbiota present in the gut of honeybees possess antibacterial activity. They are susceptible to antibiotic and express extracellular enzymes. Laboratory based findings allowed us to select two active isolates i.e., B. amyloliquefaciens and B. subtilis from $\mathrm{HB}$ gut with significant antibacterial potential against both Gram-positive and Gram-negative bacteria. Our further observations proved the proteniacious nature and stability of inhibitory activity under stress (high $\mathrm{pH}$ and temperature). PCR amplification of $s p o A$ and spaS genes confirmed that antibacterial activity was due to the presence of subtilin and subtilosin proteins, which are closely related to family bacteriocins. Further purification and in vivo study will help us to understand safety and toxicity of bacteriocins by determining its potential as probiotics, in food packaging and pharmaceutical applications. Additionally, this study provided preliminary proof that detailed molecular, pharmacological and chemical evaluation of compounds from HB gut bacteria may help us to find novel antibacterial compounds that could help us in solving the problem of antibiotic resistance with possibility to find effective alternatives to antibiotics.

Funding: This research did not receive any specific grant from funding agencies in the public, commercial, or not-forprofit sectors.

Conflicts of Interest: Authors declare no conflicts of interests.

\section{REFERENCES}

1. Marasini BP, Baral P, Aryal P, Ghimire KR, Neupane S, Dahal N, Singh A, Ghimire L, Shrestha K. Evaluation of antibacterial activity of some traditionally used medicinal plants against human pathogenic bacteria. Biomed Res Int. 2015 Jan 1;2015.

2. Saraiva MA, Zemolin AP, Franco JL, Boldo JT, Stefenon VM, Triplett EW, de Oliveira Camargo FA, Roesch LF. Relationship between honeybee nutrition and their microbial communities. Antonie Van Leeuwenhoek. 2015 Apr $1 ; 107(4): 921-33$. 
3. Baffoni L, Gaggìa F, Alberoni D, Cabbri R, Nanetti A, Biavati B, Di Gioia D. Effect of dietary supplementation of Bifidobacterium and Lactobacillus strains in Apis mellifera L. against Nosema ceranae. Benef Microbes. 2016 Feb $1 ; 7(1): 45-51$.

4. Beemelmanns $\mathrm{C}$, Guo H, Rischer M, Poulsen M. Natural products from microbes associated with insects. Beilstein J Org Chem. 2016 Feb 19;12(1):314-27.

5. Wu M, Sugimura Y, Iwata K, Takaya N, Takamatsu D, Kobayashi M, Taylor D, Kimura K, Yoshiyama M, Miller T. Inhibitory effect of gut bacteria from the Japanese honey bee, Apis cerana japonica, against Melissococcus plutonius, the causal agent of European foulbrood disease. J Insect Sci. 2014 Jan 1;14(1).

6. Kačániová M, Gasper J, Terentjeva M, Kunová S, Kluz M, Puchalski C. Antibacterial activity of bees gut lactobacilli against Paenibacillus larvae in vitro. Adv Res Life Sci. 2018 Apr 1;2(1):7-10.

7. Wang M, Zhao WZ, Xu H, Wang ZW, He SY. Bacillus in the guts of honey bees (Apis mellifera; Hymenoptera: Apidae) mediate changes in amylase values. Eur J Entomol. 2015 Nov 20;112(4):619.

8. Filannino P, Di Cagno R, Addante R, Pontonio E, Gobbetti M. Metabolism of fructophilic lactic acid bacteria isolated from the Apis mellifera L. bee gut: phenolic acids as external electron acceptors. Appl Environ Microbiol. 2016 Dec 1;82(23):6899-911.

9. Rangberg A, Mathiesen G, Amdam GV, Diep DB. The paratransgenic potential of Lactobacillus kunkeei in the honey bee Apis mellifera. Benef Microbes. 2015 Aug 1;6(4):513-23.

10. Kačániová M, Pavličová $S$, Haščík $P$, Kociubinski G, Kńazovická V, Sudzina M, Sudzinová J, Fikselová M. Microbial communities in bees, pollen and honey from Slovakia. Acta Microbiol Immunol Hung. 2009 Sep 1;56(3):285-95.

11. Olofsson TC, Butler Ė, Markowicz P, Lindholm C, Larsson L, Vásquez A. Lactic acid bacterial symbionts in honeybees-an unknown key to honey's antimicrobial and therapeutic activities. Int Wound J. 2016 Oct;13(5):66879.

12. Disayathanoowat $T$, Yoshiyama M, Kimura $K$, Chantawannakul $P$. Isolation and characterization of bacteria from the midgut of the Asian honey bee (Apis cerana indica). J Apic Res. 2012 Jan 1;51(4):312-9.

13. Sudhagar S, Reddy PR, Nagalakshmi G. Influence of elevation in structuring the gut bacterial communities of Apis cerana J Entomol Zool Stud. 2017.5(3):434-40.

14. Pomastowski P, Złoch M, Rodzik A, Ligor M, Kostrzewa M, Buszewski B. Analysis of bacteria associated with honeys of different geographical and botanical origin using two different identification approaches: MALDI-TOF MS and 16S rDNA PCR technique. PloS one. 2019 May 23;14(5):e0217078.

15. Yoshiyama M, Kimura K. Bacteria in the gut of Japanese honeybee, Apis cerana japonica, and their antagonistic effect against Paenibacillus larvae, the causal agent of American foulbrood. J Invertebr Pathol. 2009 Oct 1;102(2):91-6.

16. Djadouni F, Kihal M. Antimicrobial activity of lactic acid bacteria and the spectrum of their biopeptides against spoiling germs in foods. Braz Arch Biol Technol. 2012 Jun;55(3):435-44.

17. Pattabhiramaiah M, Reddy MS, Brueckner D. Detection of novel probiotic bacterium Lactobacillus spp. in the workers of Indian honeybee, Apis cerana indica. Int J Environ Sci. 2012;2(3):1134-43.

18. Vásquez A, Olofsson TC. The lactic acid bacteria involved in the production of bee pollen and bee bread. J Apic Res. 2009 Jan 1;48(3):189-95.

19. Lee FJ, Rusch DB, Stewart FJ, Mattila HR, Newton IL. Saccharide breakdown and fermentation by the honey bee gut microbiome. Environ Microbiol. 2015 Mar;17(3):796-815.

20. Ngalimat MS, Rahman RN, Yusof MT, Syahir A, Sabri S. Characterisation of bacteria isolated from the stingless bee, Heterotrigona itama, honey, bee bread and propolis. PeerJ. 2019 Aug 22;7:e7478.

21. Velho RV, Basso AP, Segalin J, Costa-Medina LF, Brandelli A. The presence of sboA and spaS genes and antimicrobial peptides subtilosin A and subtilin among Bacillus strains of the Amazon basin. Genet Mol Biol. 2013;36(1):101-4.

22. Van Belkum MJ, Martin-Visscher LA, Vederas JC. Structure and genetics of circular bacteriocins. Trends Microbiol. 2011 Aug 1;19(8):411-8.

23. Stein T, Düsterhus $S$, Stroh A, Entian KD. Subtilosin production by two Bacillus subtilis subspecies and variance of the sbo-alb cluster. Appl Environ Microbiol. 2004 Apr 1;70(4):2349-53.

24. Rokop ZP, Horton MA, Newton IL. Interactions between cooccurring lactic acid bacteria in honey bee hives. Appl Environ Microbiol. 2015 Oct 15;81(20):7261-70.

25. Khan KA, Ansari MJ, Al-Ghamdi A, Nuru A, Harakeh S, Iqbal J. Investigation of gut microbial communities associated with indigenous honey bee (Apis mellifera jemenitica) from two different eco-regions of Saudi Arabia. Saudi J Biol Sci. 2017 Jul 1;24(5):1061-8.

26. Liaqat I, Durrani Al, Zafar U, Rubab S, Faheem M, Mubin M, Raza C, Aftab N. Role of modified diet and gut microbiota in metabolic endotoxemia in mice. Archives of Microbiology. $2021 \mathrm{Jul}$ 24:1-9.

27. HUDZICKI J. 2009. Kirby-Bauer disk diffusion susceptibility test protocol. mBio,1-23

28. Rahman RN, Razak CN, Ampon K, Basri M, Zin WM, Yunus W, Salleh AB. Purification and characterization of a heat-stable alkaline protease from Bacillus stearothermophilus F1. Appl Microbiol Biotechnol. 1994 Feb 1;40(6):8227.

29. Kanwar SS, Kaushal RK, Jawed A, Gupta R, Chimni SS. Methods for inhibition of residual lipase activity in colorimetric assay: A comparative study. Indian J Biochem Biophys. ] 42: 233-7. 
30. Margesin R. 2005. Determination of enzyme activities in contaminated soil. In: Margesin R, Schinner F, editors. Monitoring and Assessing Soil Bioremediation. Berlin: Springer-Verlag, 309-320.

31. Liang YL, Zhang Z, Wu M, Wu Y, Feng JX. Isolation, screening, and identification of cellulolytic bacteria from natural reserves in the subtropical region of China and optimization of cellulase production by Paenibacillus terrae ME271. Biomed Res Int. 2014 Oct;2014: 1-13.

32. Klein C, Kaletta C, Schnell N, Entian KD. Analysis of genes involved in biosynthesis of the lantibiotic subtilin. Appl Environ Microbiol 1992 Jan 1;58(1):132-42.

33. Liaqat I, Sumbal F, Sabri AN. Tetracycline and chloramphenicol efficiency against selected biofilm forming bacteria. Curr microbiol 2009 Aug;59(2):212-20.

34. Audisio MC, Torres MJ, Sabaté DC, Ibarguren C, Apella MC. Properties of different lactic acid bacteria isolated from Apis mellifera L. bee-gut. Microbiol Res. 2011 Jan 20;166(1):1-3.

35. Audisio MC. Gram-positive bacteria with probiotic potential for the Apis mellifera L. honey bee: the experience in the northwest of Argentina. Probiotics Antimicrob oteins. 2017 Mar 1;9(1):22-31.

36. Yang SC, Lin CH, Sung CT, Fang JY. Antibacterial activities of bacteriocins: application in foods and pharmaceuticals. Front Microbiol. 2014 May 26;5:241.

37. Janashia I, Choiset Y, Rabesona H, Hwanhlem N, Bakuradze N, Chanishvili N, Haertlé T. Protection of honeybee Apis mellifera by its endogenous and exogenous lactic flora against bacterial infections. Ann Agrar Sci. 2016 Sep 1;14(3):177-81.

38. Yoshiyama M, Wu M, Sugimura Y, Takaya N, Kimoto-Nira H, Suzuki C. Inhibition of Paenibacillus larvae by lactic acid bacteria isolated from fermented materials. J Invertebr Pathol. 2013 Jan 1;112(1):62-7.

39. Agbagwa OE, Rani SD, Halami PM. Antibacterial potential components of Bacillus species and antibiotics residues in branded and unbranded honey samples from Nigeria. Afr J Biotechnol. 2017;16(2):58-64.

40. Hasali NH, Zamri Al, Lani MN, Mubarak A, Suhaili Z. Identification of lactic acid bacteria from Meliponine honey and their antimicrobial activity against pathogenic bacteria. Am -Eurasian J Sustain Agric. 2015 Sep 19;9(6):1-7.

41. Gharehyakheh S, HosseinElhamirad A, Nateghi L, Varmira K. Evaluation of Resistance to Conventional Antibiotics in Medicine by 5 Strains of Lactic Acid Bacteria Isolated from the Stomach of Honey Bee. Asian J Biol Sci. 2017;6(3).

42. Albaridi NA. Antibacterial potency of honey. International Journal of Microbiology. 2019 Jun 2;2019:1-10.

43. Raghavan KT, Jacob AA, Chandran H. Honey bee Gut flora as a Source of LAB (Lactic Acid Bacteria) with Probiotic Capabilities. J. Food Technol. 2013;105:126-34.

44. Klepzig KD, Adams AS, Handelsman J, Raffa KF. Symbioses: a key driver of insect physiological processes, ecological interactions, evolutionary diversification, and impacts on humans. Environ Entomol. 2009;38(1):67-77.

45. Sharma G, Dang S, Gupta S, Gabrani R. Antibacterial activity, cytotoxicity, and the mechanism of action of bacteriocin from Bacillus subtilis GAS101. Med Princ Pract. 2018;27(2):186-92.

46. Abriouel H, Franz CM, Omar NB, Gálvez A. Diversity and applications of Bacillus bacteriocins. FEMS Microbiol Rev. 2011; 35(1):201-32.

47. Sutyak KE, Wirawan RE, Aroutcheva AA, Chikindas ML. Isolation of the Bacillus subtilis antimicrobial peptide subtilosin from the dairy product-derived Bacillus amyloliquefaciens. J Appl Microbiol. 2008 Apr;104(4):1067-74.

48. Xu D, Co^te JC. Phylogenetic relationships between Bacillus species and related genera inferred from comparison of $3^{\prime}$ end 16S rDNA and 5' end 16S-23S ITS nucleotide sequences. Int J Syst Evol Microbiol. 2003; 53(3):695-704.

49. Albano M, Smits WK, Ho LT, Kraigher B, Mandic-Mulec I, Kuipers OP, Dubnau D. The Rok protein of Bacillus subtilis represses genes for cell surface and extracellular functions. J Bacteriol. 2005 Mar 15;187(6):2010-9.

50. Sharma G, Dang S, Gupta S, Gabrani R. Antibacterial activity, cytotoxicity, and the mechanism of action of bacteriocin from Bacillus subtilis GAS101. Med Princ Pract. 2018;27(2):186-92.

51. Shelburne CE, An FY, Dholpe V, Ramamoorthy A, Lopatin DE, Lantz MS. The spectrum of antimicrobial activity of the bacteriocin subtilosin A. J Antimicrob Chemother. 2007;59(2):297-300.

52. Burkard M, Entian KD, Stein T. Development and application of a microtiter plate-based autoinduction bioassay for detection of the lantibiotic subtilin. J Microbiol Meth. 2007; 70:179-185.

53. Suwanjinda D, Eames C, Panbangred W. Screening of lactic acid bacteria for bacteriocins by microbiological and PCR methods. Biochem Mol Biol Educ. 2007; 35:364-369.

(C) 2021 by the authors. Submitted for possible open access publication under the terms and conditions of the Creative Commons Attribution (CC BY NC) license (https://creativecommons.org/licenses/by-nc/4.0/). 